\title{
GALÁXIA STELAR
}

Lise Macpherson ${ }^{1}$

Tua voz doce

Me transporta

Faz parar o universo

Me prende naquele espaço

Entre o nosso mundo

E todos os outros

Que por ventura possam

Existir...

O timbre que atravessa

Espaço, tempo

Magnetiza, penetra

Misteriosa atração

Apaga o passado

Resolve os entraves

Desata os nós

Me leva, me eleva

Me tira do chão

A tua voz, teu tom

Me faz te esperar todas as noites

Naquela galáxia, nossa galáxia

E então, acima da lua

Abaixo das estrelas

Só eu e você, nuas.

\footnotetext{
${ }^{1}$ Heterônimo de Laura de Assis. Contato: rassis.laura@gmail.com Página: www.veredassentimentais.com.br 